\title{
Dinoroseobacter shibae gen. nov., sp. nov., a new aerobic phototrophic bacterium isolated from dinoflagellates
}

\author{
Hanno Biebl, ${ }^{1}$ Martin Allgaier, ${ }^{1}$ Brian J. Tindall, ${ }^{2}$ Michal Koblizek, ${ }^{3}$ \\ Heinrich Lünsdorf, ${ }^{1}$ Rüdiger Pukall ${ }^{2}$ and Irene Wagner-Döbler ${ }^{1}$ \\ ${ }^{1}$ GBF - Gesellschaft für Biotechnologische Forschung, Mascheroder Weg 1, D-38124 \\ Braunschweig, Germany \\ ${ }^{2} \mathrm{DSMZ}$ - Deutsche Sammlung von Mikroorganismen und Zellkulturen, Mascheroder Weg $1 \mathrm{~b}$, \\ D-38124 Braunschweig, Germany \\ ${ }^{3}$ Institute of Microbiology \& Institute of Physical Biology, Opatovicky mlyn, CZ-379 81 Trebon, \\ Czech Republic
}

Correspondence Irene Wagner-Döbler iwd@gbf.de

\begin{abstract}
A novel group of aerobic anoxygenic phototrophic bacteria was isolated from marine dinoflagellates, and two strains were characterized in detail. Cells were Gram-negative cocci or ovoid rods and were motile by means of a single, polarly inserted flagellum. They were obligate aerobes requiring $1-7 \%$ salinity. The optimal $\mathrm{pH}$ range for growth was $6 \cdot 5-9 \cdot 0$ and the temperature optimum was $33^{\circ} \mathrm{C}$. The bacteria contained bacteriochlorophyll $a$ and spheroidenone as the only carotenoid. The in vivo absorption spectrum displayed two maxima in the infrared region at 804 and $868 \mathrm{~nm}$. The distinct $804 \mathrm{~nm}$ band indicates the presence of light-harvesting system 2. Various organic carbon sources were assimilated, including many carboxylic acids, glucose and glycerol, but not butyrate, ethanol or methanol. Dissimilatory nitrate reduction was found for both strains. The physiological characteristics of the new strains resembled those of Roseobacter denitrificans, but there were differences in the lipid composition. Based on 16S rRNA gene sequence analysis the new strains are relatively distant from other recognized species, with the closest relatives Jannaschia helgolandensis, Ruegeria atlantica and Rhodobacter veldkampii showing 94.1-93.4\% similarity. Similarity to Roseobacter denitrificans was only $92 \cdot 2 \%$, in line with numerous other species of the Roseobacter group. Therefore, it is proposed to classify the strains in a new genus and species within the Roseobacter clade, Dinoroseobacter shibae gen. nov., sp. nov. The type strain is DFL $12^{\top}$ $\left(=\mathrm{DSM} 16493^{\top}=\mathrm{NCIMB} 14021^{\top}\right)$.
\end{abstract}

\section{INTRODUCTION}

Aerobic anoxygenic phototrophs (AAPs) were discovered at the end of the 1970s in the Bay of Tokyo (Shiba et al., 1979). These bacteria are related to the facultatively anaerobic purple non-sulfur bacteria, but during evolution they became adapted to an aerobic atmosphere and became

Published online ahead of print on 14 January 2005 as DOI 10.1099/ ijs.0.63511-0.

This paper is dedicated to Professor Norbert Pfennig on the occasion of his 80th birthday.

Abbreviation: AAP, aerobic anoxygenic phototroph.

The GenBank/EMBL/DDBJ accession number for the 16S rRNA gene sequence of strain DFL $12^{\top}$ is AJ534211.

A phase-contrast micrograph of cells of strain DFL $12^{\top}$, plus graphs of temperature and $\mathrm{pH}$ dependence for growth of the two strains are available as supplementary figures in IJSEM Online. obligate aerobes with a heterotrophic metabolism (Yurkov \& Beatty, 1998). They are capable of photosynthetic electron transfer under aerobic conditions without generation of oxygen (i.e. they are anoxygenic). Two of the first isolates were later classified as Erythrobacter longus and Roseobacter denitrificans, establishing two major genera of AAPs (Shiba \& Simidu, 1982; Shiba, 1991). Significant anoxygenic photosynthesis was discovered in the open ocean as a result of kinetic measurements of bacteriochlorophyll $a$ fluorescence emission (Kolber et al., 2000). This activity was related to the presence of AAPs, which were estimated to comprise about $10 \%$ of the total bacterial community in the North East Pacific (Kolber et al., 2001). The ability of organisms to utilize light energy as a supplement to respiratory metabolism seems to be an effective strategy in nutrient-poor marine environments (Kolber et al., 2001). Using cultivation-independent molecular methods it has been found that bacteria related to the genus Roseobacter 
constitute a substantial fraction of the marine bacterioplankton (e.g. Zubkov et al., 2001; Pinhassi \& Berman, 2003; Selje et al., 2004). However, high $16 S$ rRNA gene sequence similarity among members of the group does not guarantee the presence of phototrophic metabolism because the Roseobacter clade contains both photoheterotrophic as well as purely heterotrophic bacteria. To overcome this uncertainty, Béjà et al. (2002) selectively probed for the presence of pufM bacterial reaction centre genes and found that bacteria related to the Roseobacter clade probably form the major portion of the marine photoheterotrophic community.

Recently we surveyed a greater number of marine habitats for the presence of pigmented bacterial strains (Allgaier et al., 2003). Putative photosynthetic activity was tested by probing for the presence of the pufL and pufM genes. Of 113 bacterial strains, 16 were shown to be positive for these genes. Using $16 \mathrm{~S}$ rRNA gene sequence analyses these were classified into five phylogenetic groups. One group was yellow coloured, three showed only very weak pink pigmentation if at all, and one exhibited an intense red or pink pigment and contained fairly high levels of bacteriochlorophyll $a$. Cell morphology and culture properties of members of this last group resembled those of Roseobacter species, but their 16S rRNA gene sequences indicated only a distant relationship. Here we present a detailed characterization of this group. The results suggest classifying the group as a new genus and species within the Roseobacter clade.

\section{METHODS}

Isolation. The two strains investigated were obtained from washed single cells of cultivated marine dinoflagellates plated onto an agar surface (Allgaier et al., 2003). Strain DFL $12^{\mathrm{T}}$ was isolated from cells of Prorocentrum lima on a sea water medium containing $1 \mathrm{~g}$ tryptone and $0.5 \mathrm{~g}$ yeast extract per litre; strain DFL 27 was isolated from Alexandrium ostenfeldii on a sea water medium containing $40 \mathrm{mg}$ peptone and $8 \mathrm{mg}$ yeast extract per litre.

Cultivation. For general characterization the strains were grown in a complex medium containing $20 \mathrm{~g}$ sea salts (Sigma), 3 g Bacto peptone (Difco) and $0.5 \mathrm{~g}$ yeast extract (Difco) per litre (hereafter PY medium). In some tests a defined medium was used containing $20 \mathrm{~g}$

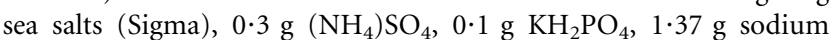
acetate, $1 \mathrm{ml}$ trace element solution SL12 (Pfennig \& Trüper, 1992), $5 \mathrm{ml}$ vitamin solution and $0.8 \mathrm{ml} 0.5 \mathrm{M} \mathrm{H}_{2} \mathrm{SO}_{4}$ per litre. Phosphate was added from a separately autoclaved $10 \%$ solution, $\mathrm{pH} 7 \cdot 5$. The filter-sterilized vitamin solution contained $2 \mathrm{mg}$ biotin, $10 \mathrm{mg}$ thiamine- $\mathrm{HCl}, 20 \mathrm{mg}$ nicotinic acid, $5 \mathrm{mg}$ pantothenic acid, $5 \mathrm{mg}$ vitamin $\mathrm{B}_{12}, 8 \mathrm{mg}$ pyridoxin and $8 \mathrm{mg} 4$-aminobenzoic acid per litre. Growth temperature was $30^{\circ} \mathrm{C}$. If not otherwise indicated the cultures were incubated in the dark. Other growth conditions are given in the respective tests. Growth was measured turbidometrically at $600 \mathrm{~nm}$, or at $650 \mathrm{~nm}$ if photosynthetic pigments were concerned. For long-term storage, $0.5 \mathrm{ml}$ culture was mixed with $0.75 \mathrm{ml}$ sterile $88 \%$ glycerol and maintained at $-70{ }^{\circ} \mathrm{C}$.

Electron microscopy. Mid-exponentially growing cells were adsorbed onto carbon-Formvar foils for $1 \mathrm{~min}$. Cells were washed once with water, blotted and air-dried. They were shadow-cast at $15^{\circ}$ elevation with platinum-carbon and analysed with an energyfiltered transmission electron microscope (CEM902; Zeiss) as described by Golyshina et al. (2000). Embedding and thin-sectioning were performed as described by Yakimov et al. (1998).

Physiological and biochemical tests. All tests that required liquid cultures were performed in $22.5 \mathrm{ml}$ metal-capped test tubes containing $5 \mathrm{ml}$ medium. For determination of the salt requirement, Sigma sea salts in PY medium were used in concentrations up to $10.5 \%$. For determination of temperature range and optimum for growth, a temperature gradient shaking incubator (Toyo Kogaku Sangyo Co. Ltd) was available that allowed us to create a gradient between 15 and $45^{\circ} \mathrm{C}$ at intervals of $3{ }^{\circ} \mathrm{C}$, if six strains were incubated simultaneously. At suitable time intervals the optical density was measured, and from the resulting growth curves the maximum growth rate at each temperature was calculated. The defined medium was used with addition of $0.5 \mathrm{~g}$ yeast extract $l^{-1}$. The $\mathrm{pH}$ range was tested at intervals of 0.5 units between $\mathrm{pH} 5.0$ and 9.5 (heavy precipitation prevented preparation of media with higher $\mathrm{pH}$ values). The $\mathrm{pH}$ was readjusted after autoclaving, the medium was distributed to the tubes and the $\mathrm{pH}$ rechecked after inoculation. Growth was measured at an early stage of the growth phase before the $\mathrm{pH}$ was appreciably changed by growth. Usable carbon sources were tested in the synthetic medium, in which the vitamin solution was replaced by $0 \cdot 1 \mathrm{~g}$ yeast extract $1^{-1}$. The carbon sources were used at a concentration of $1 \mathrm{~g} \mathrm{l}^{-1}$. General growth factor requirements, including amino acids, were determined by investigating growth in the above synthetic medium without vitamins, with vitamins, with $1 \mathrm{~g}$ yeast extract $1^{-1}$, and with vitamin-free and vitamin-containing Casamino acids (Difco). Requirement for single vitamins was determined in mixtures of seven vitamins from which one was omitted. Precultures were grown in a medium without any growth factors.

Degradation of polymers was tested on agar plates by using PY medium. Starch was added at $2 \mathrm{~g}^{-1}$, alginate at $7 \cdot 5 \mathrm{~g} \mathrm{l}^{-1}$, and Tween 80 and gelatin at $4 \mathrm{~g} \mathrm{l}^{-1}$. Starch degradation was demonstrated with Lugol's solution, alginate degradation by clear zones around the colonies, reaction with Tween 80 by bubble formation (Labrenz, 1999) and gelatin liquefaction by precipitation of undigested gelatine with saturated ammonium sulfate solution. Nitrate reduction capacity was checked in $22.5 \mathrm{ml}$ tubes with $10 \mathrm{ml}$ synthetic medium supplemented by $0.4 \mathrm{~g} \mathrm{NaNO}_{3}$ and $0.5 \mathrm{~g}$ yeast extract $l^{-1}$. Nitrogen formation was demonstrated in Durham tubes, and formation of nitrite and consumption of nitrate with Merckoquant test sticks (Merck). The presence of catalase and oxidase and formation of indol was demonstrated according to Gerhardt et al. (1981).

Photosynthetic pigments, lipids and fatty acids. The in vivo absorption spectrum was recorded in a Shimadzu UV-3000 double beam spectrophotometer with a resolution of $0.5 \mathrm{~nm}$, using a $2 \mathrm{~nm}$ slit width. Scattering was reduced by suspending centrifuged PY grown cells in $70 \%$ glycerol. Photosynthetic pigments were extracted in a mixture of acetone/methanol $(7: 2)$. A pellet of about $10 \mathrm{ml}$ culture was resuspended in the remaining drop of medium, $1 \mathrm{ml}$ of the solvent mixture was added and the suspension was incubated for $1 \mathrm{~h}$ at room temperature in the dark, vortexed and centrifuged at $9000 \mathrm{~g}$. The bacteriochlorophyll a content was determined at $772 \mathrm{~nm}$ using an extinction coefficient of $75 \mathrm{mM}^{-1} \mathrm{~cm}^{-1}$ (Clayton, 1963).

Pigment composition was analysed by HPLC using a Beckman system comprising a Beckman 420 controller, two Beckman 114M pumps and a Waters 990 photodiode array detector. Pigments were separated on a heated $\left(40{ }^{\circ} \mathrm{C}\right)$ VYDAC $\mathrm{C} 18$ column using a binary solvent system (A: $80 \%$ methanol $+0.5 \mathrm{M}$ ammonium acetate; $\mathrm{B}$ : methanol/acetone, $80: 20$ ). The peak identity was confirmed by absorption spectra and retention times. Major carotenoid molecular mass was determined by 
an offline injection into the Agilent 1100 Series LC/MSD Trap mass spectrometer. In parallel, the carotenoids were also characterized by TLC. One hundred micrograms of freeze-dried cell material was extracted in $9.5 \mathrm{ml}$ of a chloroform/methanol $/ 0.3 \% \mathrm{NaCl}$ mixture in a ratio of $1: 2: 0 \cdot 8$ under continuous stirring overnight. The mixture was extracted by hexane to record the overall absorption spectrum. The solution was then concentrated by evaporation and chromatographed in tertiary butyl ether on silica gel plates.

Lipoquinones and polar lipids were extracted and separated according to the methods described by Tindall (1990a, b). Fatty acid composition was determined by the method described by Labrenz et al. (1998). The $\mathrm{G}+\mathrm{C}$ content of the DNA was determined by HPLC (Mesbah et al., 1989).

165 rRNA gene sequences and phylogenetic inferences. DNA extraction, amplification and sequencing of the $16 \mathrm{~S}$ rRNA gene were as described by Allgaier et al. (2003). Sequences were manually aligned and compared to sequences published previously. These were stored in the DSMZ internal database, consisting of more than 6000 16S rRNA gene sequence entries, including those from the Ribosomal Database Project (Maidak et al., 1999) and EMBL. Similarity values were transformed into phylogenetic distance values that compensate for multiple substitutions at any given site in the sequence (Jukes \& Cantor, 1969). The algorithm of De Soete (1983) and the neighbour-joining method contained in the PHYLIP package (Felsenstein, 1993) were used in the construction of the phylogenetic dendrogram. All analyses were performed on a SUN SparcII workstation.

\section{RESULTS AND DISCUSSION}

\section{Morphological features}

A typical feature of strains DFL $12^{\mathrm{T}}$ and DFL 27 is their relatively strong pigmentation. Liquid cultures grown in the dark appear distinctly pink or light red. When grown under strong illumination they are faintly beige. Streaks and colonies on complex agar media are deeply wine-red, with an intensity comparable to that of anaerobic phototrophs. Colonies are convex and smooth with entire margins. Cells are small cocci, occasionally oval rods, homogeneous in synthetic medium but somewhat variable in complex media (see Fig. A, available as supplementary material in IJSEM Online) and measure $0 \cdot 3-0 \cdot 7 \mu \mathrm{m}$ in width and $0 \cdot 3-1 \cdot 0$ (to $2 \cdot 0) \mu \mathrm{m}$ in length. Cell motility was observed in all the media used. Electron micrographs of whole cells revealed extracellular polymer substances of homogeneous or varying consistency, but capsule-free cells were also found in the same preparation (Fig. 1). Flagellation is monotrichous and shows a polar to subpolar insertion (Fig. 1a). Ultra-thin sections revealed a Gram-negative cell wall structure with a distinct outer membrane, an electron-translucent periplasmic space and a faint cytoplasmic membrane; the murein layer was not visible (Fig. 1b).

\section{Physiological characteristics}

Both strains grew between 15 and $38^{\circ} \mathrm{C}$, half maximum to maximum growth was observed between 25 and $37^{\circ} \mathrm{C}$, optimum growth at $33^{\circ} \mathrm{C}$ and the upper limit at $38^{\circ} \mathrm{C}$ (see Fig. B, available as supplementary material in IJSEM

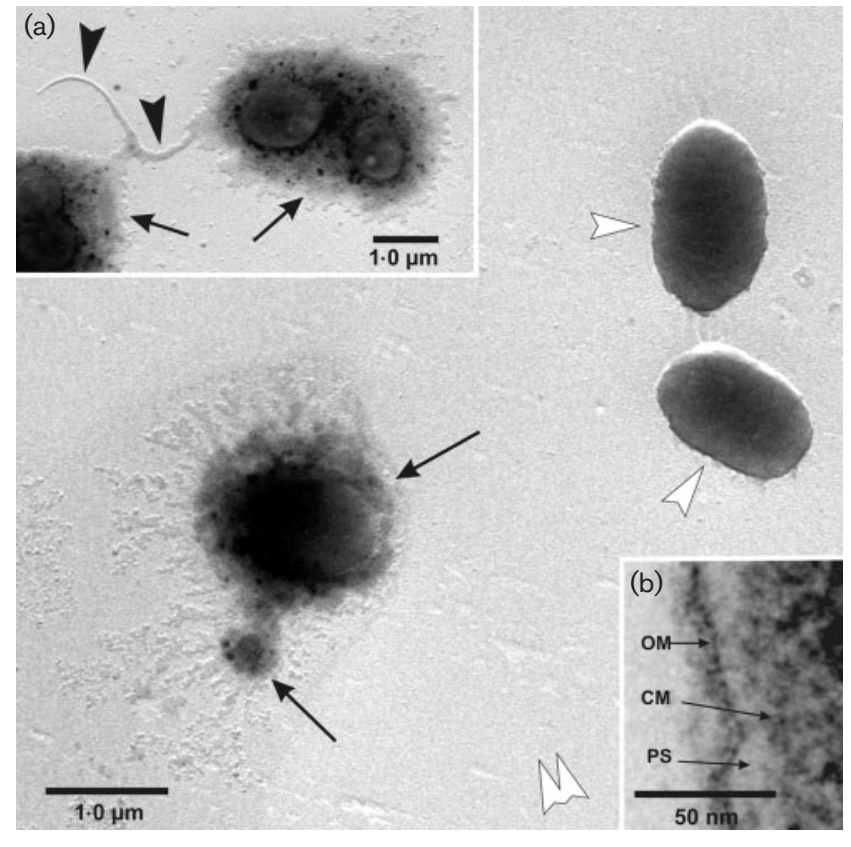

Fig. 1. Electron micrographs of cells of strain DFL $12^{\top}$. Typically, short rod-shaped cells appear either free (white arrowheads) or encapsulated by extracellular polymer substances (arrows). The twin-arrowhead indicates the shadowing direction. (a) A single flagellum (black arrowheads) inserted at the polar region of the cell. (b) Gram-negative cell wall structure (ultra-thin section): OM, outer membrane; CM, cytoplasmic membrane; PS, periplasmic space.

Online). Strain DFL 27 grew at a lower rate than strain DFL $12^{\mathrm{T}}$ (optimum at $0 \cdot 17 \mathrm{~h}^{-1}$ and $0 \cdot 12 \mathrm{~h}^{-1}$, respectively). The $\mathrm{pH}$ range for half maximum to maximum growth was found between 6.2 and $8.9\left(\right.$ DFL $12^{\mathrm{T}}$ ) and between 6.6 and $9 \cdot 0$ (DFL 27), the optimum range between $6 \cdot 5$ and $8 \cdot 8$ $\left(\right.$ DFL $12^{\mathrm{T}}$ ) and between $7 \cdot 0$ and $8 \cdot 8$ (DFL 27); no growth occurred above $\mathrm{pH} 9 \cdot 2$ (see Fig. C, available as supplementary material in IJSEM Online). The two strains were strictly salt-dependent and required at least $1 \%$ salinity. Good growth still occurred at a salt concentration twice that of normal sea water $(7 \%)$.

The strains utilized a wide spectrum of organic substances (Table 1), but not ethanol or methanol. In contrast to the four other groups of aerobic phototrophs isolated from dinoflagellates, butyrate was not metabolized. Interestingly, Roseobacter denitrificans and Roseobacter litoralis showed an almost identical pattern of substrate utilization, including the inability to grow on butyrate. By contrast, Jannaschia helgolandensis (Wagner-Döbler et al., 2003), which has the highest $16 \mathrm{~S}$ rRNA gene sequence similarity to the two strains, displays a substantially different pattern of carbon source utilization (Table 1). Anaerobic growth was not observed, either photoheterotrophically on acetate in the light or by fermentation of glucose in the dark. There was 
Table 1. Differences in utilization of organic carbon sources between strains DFL $12^{\mathrm{T}} / \mathrm{DFL} 27$ and Roseobacter denitrificans, Roseobacter litoralis and J. helgolandensis

Taxa: 1, DFL 12 $2^{\mathrm{T}}$ DFL 27; 2, R. denitrificans (Shioi, 1986); 3, $R$. litoralis (Shiba, 1991); 4, J. helgolandensis (Wagner-Döbler et al., 2003). +, Utilized; -, not utilized; W, weakly utilized; NT, not tested.

\begin{tabular}{|lcccc|}
\hline Carbon source & $\mathbf{1}$ & $\mathbf{2}$ & $\mathbf{3}$ & $\mathbf{4}$ \\
\hline Acetate & + & $\mathrm{W}$ & + & - \\
Succinate & + & $\mathrm{W}$ & + & + \\
Fumarate & + & + & $\mathrm{NT}$ & $\mathrm{NT}$ \\
Lactate & + & + & $\mathrm{NT}$ & + \\
Citrate & + & $\mathrm{W}$ & + & + \\
Glutamate & + & + & + & - \\
Pyruvate & + & + & + & - \\
Fructose & + & + & $\mathrm{NT}$ & + \\
Ethanol & $\mathrm{W} /-$ & - & $\mathrm{NT}$ & $\mathrm{NT}$ \\
Glycerol & + & + & $\mathrm{NT}$ & + \\
\hline
\end{tabular}

no indication for preferred growth under microaerobic conditions.

The new isolates were unable to grow in a pure mineral medium containing the carbon source only, as they required addition of yeast extract. The yeast extract could be entirely replaced by a mixture of biotin, nicotinic acid and 4aminobenzoic acid (Table 2). Amino acids were not necessary for growth. According to Shiba (1991), biotin, nicotinic acid and thiamin are required by Roseobacter species.

Of the polymers tested, gelatine and Tween 80 (indicating lipase activity) were hydrolysed, but not starch or alginate (Table 2). The two strains were sensitive to penicillin G, tetracycline, chloramphenicol and polymyxin $\mathrm{B}$, as are Roseobacter species. Nitrate reduction and nitrogen production were positive for both strains. Intermediary nitrite was not detected. Under aerobic conditions, nitrate was used as nitrogen source. Tests for catalase and oxidase were positive; indol was not formed.

\section{Chemotaxonomic characteristics}

The predominant respiratory lipoquinone was ubiquinone 10 , which is characteristic for the $\alpha$-Proteobacteria. The cellular polar lipids differed distinctly from those of Roseobacter species (Table 2). Phosphatidylglycerol and diphosphatidylglycerol were present, but not phosphatidylcholine as in Roseobacter denitrificans. An unidentified aminolipid was found in addition to an array of eight to ten unidentified substances. The polar lipid pattern of J. helgolandensis showed less similarity to DFL $12^{\mathrm{T}}$ and DFL 27 (Table 2). The predominant cellular fatty acid was $18: 1 \omega 7 c(75-82 \%$ of the total), which is common among the $\alpha$-Proteobacteria (Table 3). Five other fatty acids, two of them only tentatively identified, compose between 2 and $6 \%$ of the total,
Table 2. Physiological and biochemical characteristics of strains DFL $12^{\top}$ and DFL 27 in comparison to Roseobacter denitrificans, Roseobacter litoralis and J. helgolandensis

Taxa: 1, DFL $12^{\mathrm{T}} /$ DFL 27; 2, R. denitrificans DSM $7001^{\mathrm{T}}$ (Shiba, 1991; Labrenz et al., 1999); 3, R. litoralis DSM 6996 ${ }^{\mathrm{T}}$ (Shiba, 1991; Labrenz et al., 1999); 4, J. helgolandensis DSM $14858^{\mathrm{T}}$ (Wagner-Döbler et al., 2003). NT, Not tested.

\begin{tabular}{|lcccc|}
\hline Characteristic & $\mathbf{1}$ & $\mathbf{2}$ & $\mathbf{3}$ & $\mathbf{4}$ \\
\hline Bacteriochlorophyll $a$ & + & + & + & - \\
Nitrate reduction & + & + & - & - \\
Gelatin hydrolysed & + & + & + & - \\
Tween 80 hydrolysed & + & + & + & - \\
Vitamins required: & + & + & + & + \\
$\quad$ Biotin & + & + & + & NT \\
Nicotinic acid & + & + & + & NT \\
Thiamin & - & + & + & NT \\
4-Aminobenzoic acid & + & NT & NT & NT \\
Polar lipids: & & & & \\
$\quad$ Phosphatidylethanolamine & - & - & - & + \\
Phosphatidylcholine & - & + & - & + \\
$\quad$ Unidentified aminolipid & + & - & - & + \\
$\quad$ Other polar lipids & 8 & - & - & 1 \\
\hline
\end{tabular}

and a sixth compound, tentatively identified as methyl $18: 1$, occurs only in strain DFL 27 . The fatty acid pattern was similar to that of Roseobacter species but distinct from that of J. helgolandensis.

\section{Photosynthetic pigments}

Fig. 2 shows the in vivo absorption spectrum together with the acetone/methanol extract spectrum. Both display specific bacteriochlorophyll $a$ peaks, at 373, 590, 804 and $868 \mathrm{~nm}$ in vivo and at 367, 590 and $775 \mathrm{~nm}$ in solvent. The infrared region of the in vivo spectrum, with a lower peak at 804 and a higher peak at $868 \mathrm{~nm}$, corresponds to that of many other phototrophic bacteria (Yurkov \& Beatty, 1998). The distinct absorption band at $804 \mathrm{~nm}$ is indicative of the presence of light-harvesting complex 2 as observed in the Roseobacter species (Shiba, 1991). Interestingly, recently isolated marine Roseobacter strains are entirely devoid of light-harvesting system 2, although they appear otherwise very similar to the strains described herein (M. Koblizek, P. G. Falkowski \& Z. S. Kolber, unpublished results). The absolute amount of bacteriochlorophyll $a$ reached values of $4 \mathrm{nmol}$ (mg protein $)^{-1}$, which is among the highest yet published for aerobic phototrophs (Harashima et al., 1980; Yurkov \& van Gemerden, 1993). It was formed only in the dark and was increased under conditions of nutrient deficiency.

The absorption in the range $400-600 \mathrm{~nm}$ is due to a carotenoid. Its maximum of $482 \mathrm{~nm}$ in the solvent extract is almost identical to that of Roseobacter denitrificans and indicates spheroidenone as a major component (Harashima \& Nakada, 1983).The identity of the pigments was 
Table 3. Cellular fatty acid composition of strains DFL $12^{\top}$ and DFL 27 in comparison to Roseobacter denitrificans, Roseobacter litoralis and J. helgolandensis

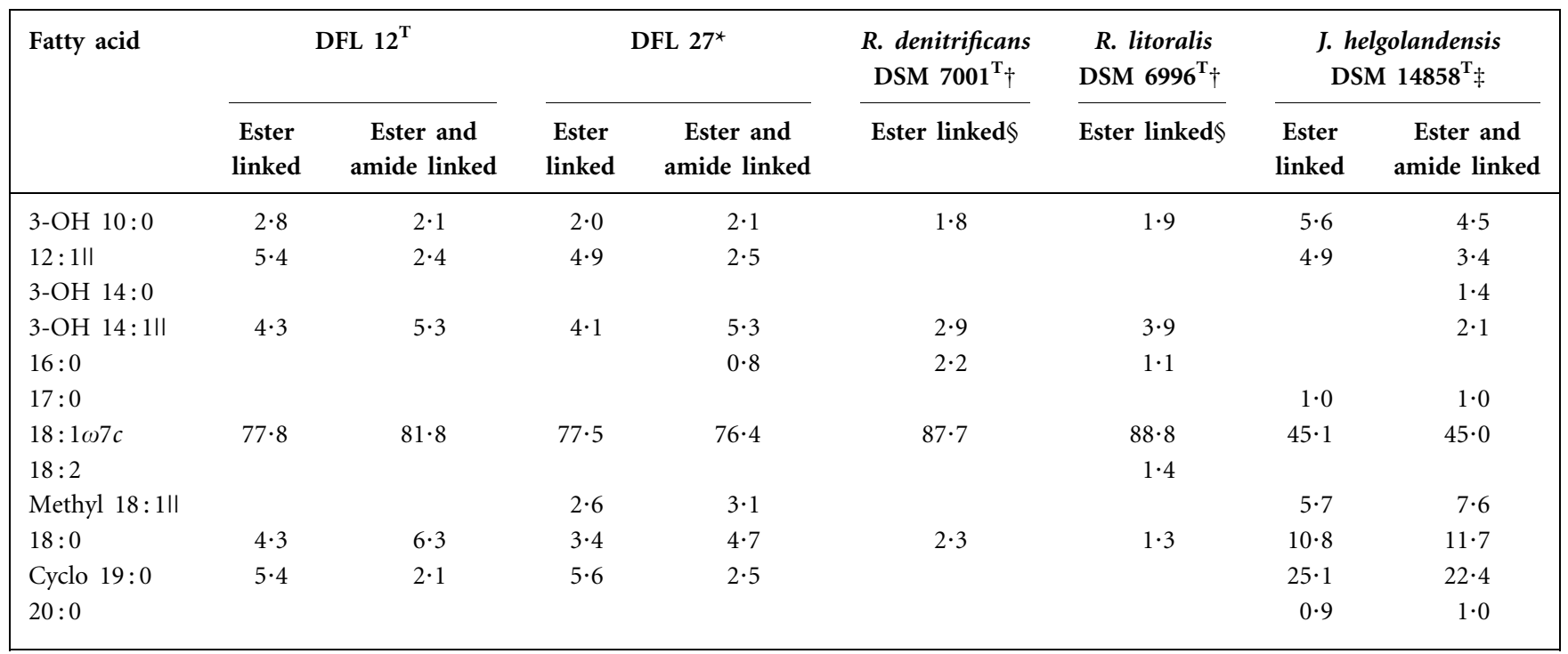

${ }^{\star}$ Strain DFL 27 contained three additional unidentified substances amounting to $0 \cdot 8,0 \cdot 6$ and $1 \cdot 0 \%$ of the total.

$\dagger$ Labrenz et al. (1999).

¥Wagner-Döbler et al. (2003).

$\S B$. J. Tindall, personal communication.

IINot unambiguously identified for DFL $12^{\mathrm{T}}$ and DFL 27.

confirmed by HPLC (Fig. 3). Based on its retention time, bacteriochlorophyll $a$ contained a phytyl side chain as found in other AAPs. In the HPLC analysis, only one major (90\%) carotenoid was detected. This was identified as spheroidenone based on the absorption spectrum, retention time and mass spectrometry. Its identity was confirmed by

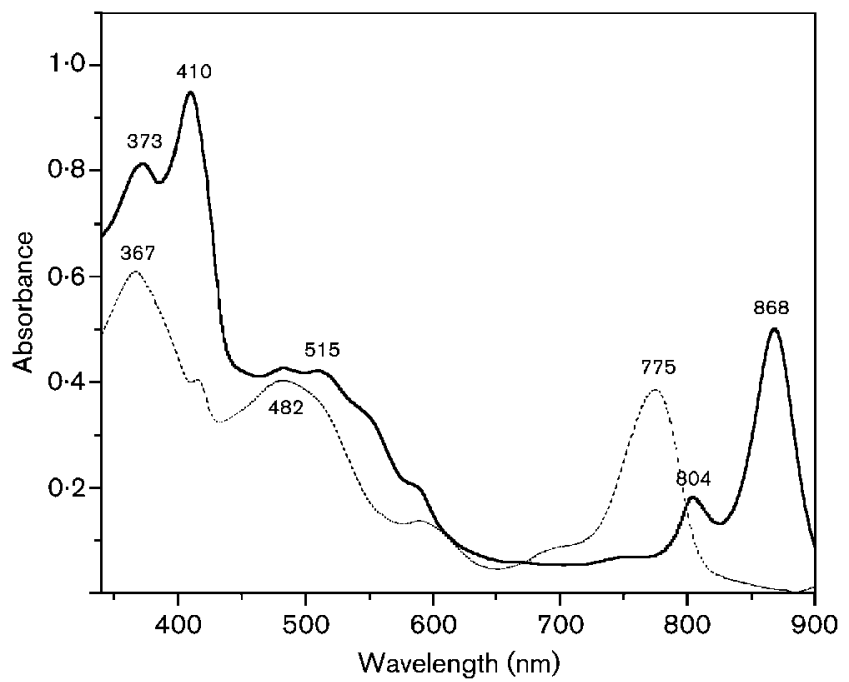

Fig. 2. Absorption spectra of strain DFL $12^{\top}$, obtained in vivo from isolated membrane particles, acetone/methanol extract $(7: 2)$. control extracts obtained from Roseobacter denitrificans and semi-aerobically grown Rhodobacter sphaeroides. TLC in tertiary butyl ether yielded two incompletely separated fractions with main absorption maxima in hexane at 479 and $482 \mathrm{~nm}$, respectively; the raw extract peaked in between $(481 \mathrm{~nm})$. Exactly the same result was obtained with extracts of Roseobacter denitrificans. In the HPLC chromatogram, the presence of two fractions could also be inferred from

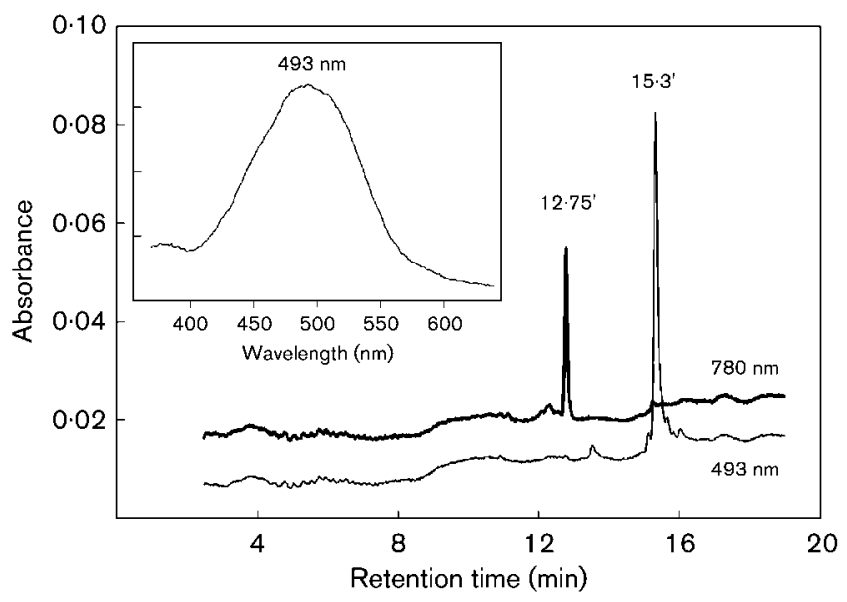

Fig. 3. Reversed-phase HPLC chromatogram of strain DFL 27 for bacteriochlorophyll a recorded at $780 \mathrm{~nm}$ and for spheroidenone recorded at $493 \mathrm{~nm}$. Inset: on-line absorption of spheroidenone taken by diode array. 
an asymmetric carotenoid peak. It is presumed that the two fractions represent cis and trans isomers of the same substance.

In experiments with washed cells, the effect of light on proton translocation and ATP formation is currently being studied by H. Cypionka (personal communication; for methods, see Sydow et al., 2002). On illumination an increase in extracellular $\mathrm{pH}$ was observed, and the intracellular concentration of ATP increased considerably, indicating the presence of a functional photosynthetic apparatus. Moreover, oxygen uptake was impaired when the cells were exposed to light, as has been described previously by Harashima et al. (1982) for Roseobacter and Erythrobacter species.

\section{Phylogenetic analysis}

The phylogenetic position of strains DFL $12^{\mathrm{T}}$ and DFL 27 was ascertained using about $1260 \mathrm{nt}$ of the $16 \mathrm{~S}$ rRNA gene sequence. About 100 bases at the beginning and the end of the Escherichia coli sequence were not analysed. Comparison of the secondary structure of both sequences resulted in the detection of a few differences in some of the stem-loop structures, but no differences were observed in the variable regions. The sequences obtained showed an overall similarity of $99 \cdot 7 \%$ and allowed us to classify the strains as representing members of the RoseobacterSulfitobacter-Silicibacter group (Wagner-Döbler et al., 2003 ) within the $\alpha$-Proteobacteria. The closest phylogenetic neighbours of strain DFL $12^{\mathrm{T}}$ were J. helgolandensis (Wagner-Döbler et al., 2003), Ruegeria atlantica and Rhodobacter veldkampii with similarity values of $94 \cdot 1,93 \cdot 7$ and $93.4 \%$, respectively. $16 \mathrm{~S}$ rRNA gene sequence similarity values for the majority of the available relevant type strains ranged between 92 and $93 \%$, making it difficult to mark a well-defined position in a possible lineage. The dendrogram obtained (Fig. 4) therefore has a relatively labile constitution and might change substantially if additional strains are included.

Regardless, the two presented strains are relatively distant neighbours from recognized species, which suggests that they should be classified within a separate genus. The apparent similarity to Roseobacter in pigmentation, morphology and physiological characters is not substantiated by $16 \mathrm{~S}$ rRNA gene sequence analysis, suggesting that the strains are no more related to the type strains of Roseobacter species than they are to any other strain belonging to the Roseobacter clade. This conclusion is also supported by the rather specific polar lipid patterns of the two strains. In addition, the $\mathrm{G}+\mathrm{C}$ content $(64 \cdot 8 \mathrm{~mol} \%)$ falls outside

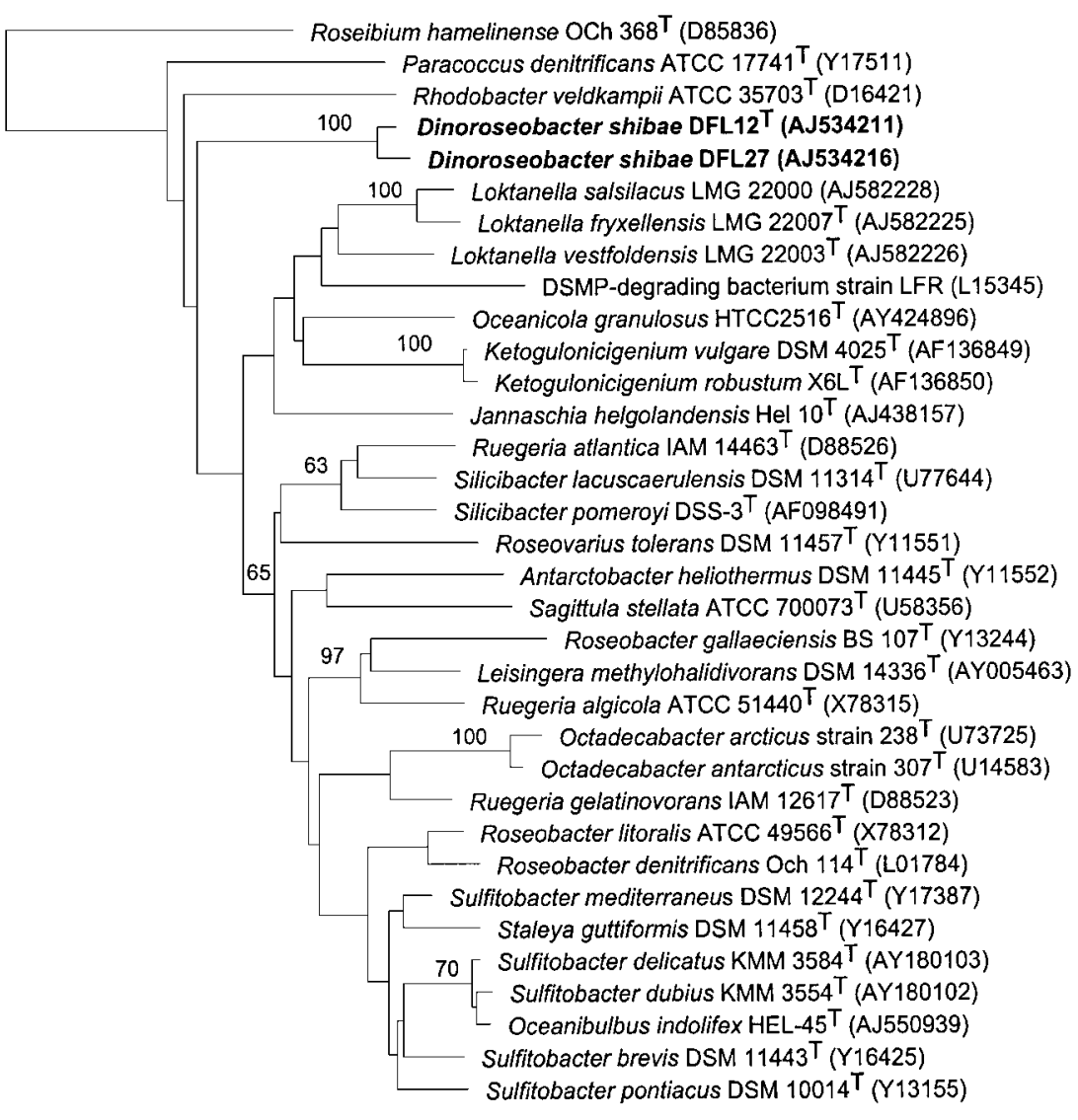

$5 \%$
Fig. 4. Neighbour-joining dendrogram based on 16S rRNA gene sequences showing the phylogenetic position of Dinoroseobacter shibae, strains DFL $12^{\top}$ and DFL 27, within the $\alpha$-Proteobacteria. Bootstrap values with greater than $60 \%$ confidence are shown at branching points (percentages of 400 replicates). Bar, 5 nucleotide substitutions per 100 sequence positions. The tree was rooted with Escherichia coli as outgroup. Sequence accession numbers are given in parentheses. 
the range of values reported for the genus Roseobacter $(56 \cdot 7-59 \cdot 6 \mathrm{~mol} \%)$. On the other hand, the strains showed only little similarity to $J$. helgolandensis with regard to phenotypic characters, including lack of phototrophy, and different physiological properties, fatty acids and polar lipids. However, with regard to phototrophy, it has been repeatedly shown in recent years that the presence of the photosynthetic apparatus is only of weak taxonomic relevance, and phototrophic and non-phototrophic strains have been grouped within the same genus or even species (Ruiz-Ponte et al., 1998; Labrenz et al., 1999; Hiraishi et al., 2000). For Rhodobacter, a 16S rRNA gene sequence similarity equal to that of members of the Roseobacter group was unexpected, as Rhodobacter performs anaerobic photosynthesis. Relatedness between Roseobacter and Rhodobacter was known, however, and as inferred from 16S rRNA gene sequence analysis the new strains are somewhat closer to Rhodobacter than to Roseobacter species.

\section{Description of Dinoroseobacter gen. nov.}

Dinoroseobacter [Di' no.ro'se.o.bac.ter. Gr. n. dinos whirling, rotation, and the first compound of the Protozoan name Dinophyceae (dinoflagellates), the source from which the isolates were obtained; N.L. n. Roseobacter a bacterial genus; N.L. masc. n. Dinoroseobacter a Roseobacter-like organism originating from dinoflagellates].

Gram-negative cocci or ovoid rods. Motile by a single, polarly or subpolarly inserted flagellum. Liquid cultures pink to light red if grown in the dark or intermittent light; faint beige if grown in permanent light. Dark-grown colonies are wine-red. Strictly aerobic, non-fermentative heterotrophs requiring at least $1 \%$ sea salt. Contain photosynthetic pigments, bacteriochlorophyll $a$ and spheroidenone. The predominant respiratory quinone is ubiquinone 10 .

The type species is Dinoroseobacter shibae.

\section{Description of Dinoroseobacter shibae sp. nov.}

Dinoroseobacter shibae (shi'bae. N.L. gen. n. shibae of Shiba, named after Professor Tsuneo Shiba, who discovered the marine aerobic anoxygenic phototrophic bacteria and provided fundamental contributions to the description of this physiological group of bacteria).

Pseudococci or ovoid cells, $0 \cdot 3-0 \cdot 7 \mu \mathrm{m}$ long and $0 \cdot 3-$ $1 \cdot 0 \mu \mathrm{m}$ (to $2 \cdot 0)$ wide. Uses acetate, succinate, fumarate, malate, lactate, citrate, glutamate, pyruvate, glucose, fructose and glycerol as carbon source, but not methanol, ethanol or butyrate. Requires biotin, nicotinic acid and 4aminobenzoic acid as growth factors. Nitrate is reduced to elemental nitrogen. Gelatin and Tween 80 are decomposed. The predominant fatty acid $(75-82 \%)$ is $18: 1 \omega 7 c$; 3-OH 10:1, 12:1,3-OH 14:1, 18:0 and cyclo 19:0 are present in minor amounts. The polar lipids phosphatidylglycerol, diphosphatidylglycerol, an unidentified aminolipid and several other, as-yet-unidentified lipids are present.
$\mathrm{G}+\mathrm{C}$ content of the type strain is $64 \cdot 8 \mathrm{~mol} \%$. All other properties are as for the genus.

The type strain, DFL $12^{\mathrm{T}}\left(=\operatorname{DSM} 16493^{\mathrm{T}}=\right.$ NCIMB $\left.14021^{\mathrm{T}}\right)$, was isolated from cultured cells of the marine dinoflagellate Prorocentrum lima.

\section{ACKNOWLEDGEMENTS}

The authors would like to thank Gunnar Gerdts and Antje Wichels from the Biologische Anstalt Helgoland for logistic and moral support during field trips.

\section{REFERENCES}

Allgaier, M., Uphoff, H., Felske, A. \& Wagner-Döbler, I. (2003). Aerobic anoxygenic photosynthesis in Roseobacter clade bacteria from diverse marine habitats. Appl Environ Microbiol 69, 5051-5059.

Béjà, O., Suzuki, M. T., Heidelberg, J. F., Nelson, W. C., Preston, C. M., Hamada, T., Eisen, J. A., Fraser, C. M. \& DeLong, E. F. (2002). Unsuspected diversity among marine anoxygenic phototrophs. Nature 415, 630-633.

Clayton, R. K. (1963). Absorption spectra of photosynthetic bacteria and their chlorophylls. In Bacterial Photosynthesis, pp. 495-500. Edited by H. Gest, A. San Pietro \& L. P. Vernon. Yellow Springs: Antioch Press.

De Soete, G. (1983). A least squares algorithm for fitting additive trees to proximity data. Psychometrica 48, 621-626.

Felsenstein, J. (1993). PHYLIP (phylogeny inference package), version 3.5c. Department of Genetics, University of Washington, Seattle, USA.

Gerhardt, P., Murray, R. G. E., Costilow, R. N., Nester, E. W., Wood, W. A., Krieg, N. R. \& Phillips, G. B. (1981). Manual of Methods for General Bacteriology. Washington, DC: American Society for Microbiology.

Golyshina, O. V., Pivovarova, T. A., Karavaiko, G. I. \& 7 other authors (2000). Ferroplasma acidophilum gen. nov., sp. nov., an acidophilic, autotrophic, ferrous-iron-oxidizing, cell-wall-lacking, mesophilic member of the Ferroplasmaceae fam. nov., comprising a distinct lineage of the Archaea. Int J Syst Evol Microbiol 50, 997-1006.

Harashima, K. \& Nakada, H. (1983). Carotenoid and ubiquinone in aerobically grown cells of an aerobic photosynthetic bacterium, Erythrobacter species OCh 114. Agric Biol Chem 47, 1057-1063.

Harashima, K., Hayasaki, J., Ikari, T. \& Shiba, T. (1980). $\mathrm{O}_{2^{-}}$ stimulated synthesis of bacteriochlorophyll and carotenoids in marine bacteria. Plant Cell Physiol 21, 1283-1294.

Harashima, K., Nakagawa, M. \& Murata, N. (1982). Photochemical activities of bacteriochlorophyll in aerobically grown cells of aerobic heterotrophs, Erythrobacter species (OCh 114) and Erythrobacter longus (OCh 101). Plant Cell Physiol 23, 185-193.

Hiraishi, A., Kuraishi, H. \& Kawahara, K. (2000). Emendation of the description of Blastomonas natatoria (Sly 1985) Sly and Cahill 1997 as an aerobic photosynthetic bacterium and reclassification of Erythromonas ursincola Yurkov et al. 1997 as Blastomonas ursincola comb. nov. Int J Syst Evol Microbiol 50, 1113-1118.

Jukes, T. H. \& Cantor, C. R. (1969). Evolution of protein molecules. In Mammalian Protein Metabolism, vol. 3, pp. 21-132. Edited by H. N. Munro. New York: Academic Press. 
Kolber, Z. S., Van Dover, C. L., Niederman, R. A. \& Falkowski, P. G. (2000). Bacterial photosynthesis in surface waters of the open ocean. Nature 407, 177-179.

Kolber, Z. S., Plumley, F. G., Lang, A. S. \& 7 other authors (2001). Contribution of aerobic photoheterotrophic bacteria to the carbon cycle in the ocean. Science 292, 2492-2495.

Labrenz, M. (1999). Charakterisierung ausgesuchter antarktischer Bakterien: Ökologische Ansprüche von Stämmen aus einem hypersalinen See und Versuche zur Identifizierung potentiell anthropogener Bodenisolate. Doctoral dissertation, Unversity of Kiel.

Labrenz, M., Collins, M. D., Lawson, P. A., Tindall, B. J., Braker, G. \& Hirsch, P. (1998). Antarctobacter heliothermus gen. nov., sp. nov., a budding bacterium from hypersaline and heliothermal Ekho Lake. Int J Syst Bacteriol 48, 1363-1372.

Labrenz, M., Collins, M. D., Lawson, P. A., Tindall, B. J., Schumann, P. \& Hirsch, P. (1999). Roseovarius tolerans gen. nov., sp. nov., a budding bacterium with variable bacteriochlorophyll a production from hypersaline Ekho Lake. Int J Syst Bacteriol 49, 137-147.

Maidak, B. L., Cole, J. R., Parker, C. T., Jr \& 11 other authors (1999). A new version of the RDP (Ribosomal Database Project). Nucleic Acids Res 27, 171-173.

Mesbah, M., Premachandran, U. \& Whitman, W. B. (1989). Precise measurement of the $\mathrm{G}+\mathrm{C}$ content of deoxyribonucleic acid by high-performance liquid chromatography. Int J Syst Bacteriol 39, 159-167.

Pfennig, N. \& Trüper, H. G. (1992). The family Chromatiaceae. In The Prokaryotes, 2nd edn, pp. 3200-3221. Edited by A. Balows, H. G. Trüper, M. Dworkin, W. Harder \& K.-H. Schleifer. Berlin: Springer.

Pinhassi, J. \& Berman, T. (2003). Differential growth response of colony-forming $\alpha$ - and $\gamma$-Proteobacteria in dilution culture and nutrient addition experiments from Lake Kinneret (Israel), the Eastern Mediterranean Sea, and the Gulf of Eilat. Appl Environ Microbiol 69, 199-211.

Ruiz-Ponte, C., Cilia, V., Lambert, C. \& Nicolas, J. L. (1998). Roseobacter gallaeciensis sp. nov., a new marine bacterium isolated from rearings and collectors of the scallop Pecten maximus. Int J Syst Bacteriol 48, 537-542.

Selje, N., Simon, M. \& Brinkhoff, T. (2004). A newly discovered Roseobacter cluster in temperate and polar oceans. Nature 427, 445-448.
Shiba, T. (1991). Roseobacter litoralis gen. nov., sp. nov., and Roseobacter denitrificans sp. nov., aerobic pink-pigmented bacteria which contain bacteriochlorophyll a. Syst Appl Microbiol 14, 140-145.

Shiba, T. \& Simidu, U. (1982). Erythrobacter longus gen. nov., sp. nov., an aerobic bacterium which contains bacteriochlorophyll $a$. Int J Syst Bacteriol 32, 211-217.

Shiba, T., Simidu, U. \& Taga, N. (1979). Distribution of aerobic bacteria which contain bacteriochlorophyll a. Appl Environ Microbiol 38, 43-45.

Shioi, Y. (1986). Growth characteristics and substrate specifity of aerobic photosynthetic bacterium, Erythrobacter sp. (Och 114). Plant Cell Physiol 27, 567-572.

Sydow, U., Wohland, P., Wolke, I. \& Cypionka, H. (2002). Bioenergetics of the alkaliphilic sulfate-reducing bacterium Desulfononatronovibrio hydrogenovorans. Microbiology 148, 853-860.

Tindall, B. J. (1990a). Lipid composition of Halobacterium lacusprofundi. FEMS Microbiol Lett 66, 199-202.

Tindall, B. J. (1990b). A comparative study of the lipid composition of Halobacterium saccharovorum from various sources. Syst Appl Microbiol 13, 128-130.

Wagner-Döbler, I., Rheims, H., Felske, A., Pukall, R. \& Tindall, B. J. (2003). Jannaschia helgolandensis gen. nov., sp. nov., a novel abundant member of the marine Roseobacter clade from the North Sea. Int J Syst Evol Microbiol 53, 731-738.

Yakimov, M. M., Golyshin, P. N., Lang, S., Moore, E. R. B., Abraham, W.-R., Lünsdorf, H. \& Timmis, K. N. (1998). Alcanivorax borkumensis gen. nov., sp. nov., a new hydrocarbon-degrading and surfactant-producing marine bacterium. Int J Syst Bacteriol 48, 339-348.

Yurkov, V. V. \& Beatty, J. T. (1998). Anaerobic anoxygenic phototrophic bacteria. Microbiol Mol Biol Rev 62, 695-724.

Yurkov, V. V. \& van Gemerden, H. (1993). Impact of light/dark regimen on the growth rate, biomass formation and bacteriochlorophyll synthesis in Erythromicrobium hydrolyticum. Arch Microbiol 159, 84-89.

Zubkov, M. V., Fuchs, B. M., Burkill, P. H. \& Amann, R. (2001) Comparison of cellular and biomass specific activities of dominant bacterioplankton groups in stratified waters of the Celtic Sea. Appl Environ Microbiol 67, 5210-5218. 